Ann. Génét. Sél. anim., I980, 12 (3), 233-239.

\title{
The action of the sex linked barring gene on Spanish chickens with gold plumage
}

\author{
J. L. CAMPO and F. OROZCO \\ Departamento de Genética Cuantitativa y Mejora Animal \\ Instituto Nacional de Investigaciones Agrarias \\ Carretera de La Corñ̃a Km. 7, Madrid (España)
}

\section{Summary}

This work concerns the genetic description of Spanish chickens breeds and study of the action of the sex-linked barring gene observed in gold plumage populations of Northern Spain. The crosses of Gold Barred Basque with "Castellana" (Black Spanish) show that the allele of those populations is the same as $B$. In gold birds $\left(s^{+}\right)$the $B$ allele originates non-pigmented bars alternated with black or gold bars, depending on the presence of the extended black allele $(E)$ or another allele of this locus, respectively. The latter phenotype (gold barred) does not show the typical white patch on the back of the chick head.

Concerning the E-locus allele in Basque and Prat breeds, it is tentatively concluded that the dominant wheaten allele $\left(e^{\mathrm{w} h}\right)$ is present in both breeds. The possible presence of the columbian type restriction gene in both breeds is suggested too. The dominance of $E$ over $e^{\mathrm{wh}}$ is very incomplete in presence of the barring and/or the columbian genies.

\section{Introduction}

The action of the sex-linked barring gene $(B)$ does not seem entirely understood in presence of the extended black $(E)$ and the sex-linked gold $\left(s^{+}\right)$genes. The registry of poultry genetic stocks (SomEs, I978) points out, describing $B$, that it interrupts deposition of pigment to yield a bar showing basic ground color (silver-gold). This definition may lead one to think that if a bird has the $E$ and the $s^{+}$alleles, the bars will be black and gold alternately. NICKERSON (I944) indicated that it is possible for the barring to work on other kinds of pigment than black, for instance on the brown, as that is proved by the Gold Barred Rock (Punnetit and Pease, I928) and the Barred Basque (CAmpo and Orozco, I979) breeds.

This work goes deeper into the action of the sex-linked barring gene with respect to that topic and it seeks to study its effect in presence of the $E$-locus 
alleles that are different to the extended black. A columbian restriction factor is also considered. With this genetic study of Spanish chickens information is added to the above mentioned work on Basque breeds, especially in relation to the characteristic barring factor of some populations.

\section{Material and methods}

The birds carrying the sex-linked barring gene are a variety of the Gold Basque breed described by CAMPO and OROZCO (I979), and they come from several farms of the Basque country. Closed strains of these populations have been kept in the Experimental Station of "E1 Encin " (Madrid) since 1975, as a part of a large conservation program of poultry resources. Two breeds, also from this program, have been utilized: the Black Spanish ("Castellana») and the Buff Prat. The "Castellana" has the extended black gene $(E)$ and therefore the chicks and the adults are black. The Buff Prat shows gold plumage with columbian restriction pattern.

The varieties Barred and White Plymouth Rock are also included in this study; both of them come from commercial stocks, even though the White Rock has been kept in our Department for 25 years.

To carry out the study several crosses were done as specified later on. Only one mating per type of cross was done to produce both the $F_{1}$ and $F_{2}$ generations. The number of females in each pen ranged from one to three in the first generation and from five to ten in the second generation. One or two hatches, separated by ten days, were done within each $F_{1}$ mating; the number in the $F_{2}$ generation ranged from one to three. The $F_{1}$ and the $F_{2}$ hatches were in 1978 and 1979 respectively (January to April).

No statistical tests were done between the observed and expected proportions, since the aim of the study was not quantitative but qualitative analysis only. Furthermore, the sample size in some crosses was not large enough.

The genetic terminology follows HuTr's book (I949) and the more up-todate one compiled by SomEs (1978). The $e$-symbol refers to a nondetermined allele at the E-locus from the Basque and the Prat breeds, but it does not assume equality between both of them. At present, crosses with tester strains are being done to identify these alleles and also the columbian restriction factor of both breeds.

\section{Results and discussion}

Table I summarizes the results obtained in the $F_{1}$ generation from the crosses in which the sex-linked barring factor has taken part.

\section{Mating of Barred Basque male $\times$ Black Spanish female}

The cross between a Barred Basque male (e/e) and two Black Spanish females $(E / E)$ produced barred and nonbarred black progeny of both sexes; this result was expected since the sire was dark barred and therefore heterozygous $B / b^{+}$ 
(CAmpo and Orozco, I979). The incomplete dominance of the $E$ allele was evident by the gold flecks in the hackle, saddle and wing-bows of the barred males and in the wing-bows of the nonbarred males.

The black barred phenotype was like the Barred Plymouth Rock, the most popular breed carrying the sex-linked barring factor. The white patch on the back of the head is shown in the chicks that will become barred adults. Both facts banish the idea that the barring allele from the Basque breed might be different to $B$. In order to confirm this point, the cross Barred Basque $\times$ Barred Plymouth Rock will be made in the future.

TABLE I

$F_{1}$ generation phenotypes from the matings in which the sive or the dam is carrying the sex-linked barring factor

Phénotypes de la génération $F_{1}$ provenant d'accouplements dans lesquels le male ou la femelle a le facteur barré lié au sexe

\begin{tabular}{|c|c|c|c|c|c|c|c|c|c|}
\hline \multirow{3}{*}{\multicolumn{2}{|c|}{ Mating }} & \multicolumn{8}{|c|}{ Offspring } \\
\hline & & \multicolumn{4}{|c|}{ barred } & \multicolumn{4}{|c|}{ non-barred } \\
\hline & & \multicolumn{2}{|c|}{ gold } & \multicolumn{2}{|c|}{ black } & \multicolumn{2}{|c|}{ gold } & \multicolumn{2}{|c|}{ black } \\
\hline$\sigma$ & $x$ & đa & 우 & $\pi$ & 우 & t & 우 & oే & 우 \\
\hline $\begin{array}{l}\text { Barred Basque } \\
\text { Buff Prat } \\
\text { Buff Prat } \\
\text { Barred Rock }\end{array}$ & $\begin{array}{l}\times \text { Black Spanish } . \\
\times \text { Barred Basque } . \\
\times \text { White Rock } . \\
\times \text { Non-barred } \\
\quad \text { Basque }\end{array}$ & $\begin{array}{l}-78 \\
19 \\
-\end{array}$ & $\begin{array}{l}- \\
- \\
-\end{array}$ & $\begin{array}{l}\frac{4}{19} \\
50\end{array}$ & $\frac{6}{-}$ & $\begin{array}{l}- \\
- \\
-\end{array}$ & $\begin{array}{l}\overline{-} \\
\text { I5 } \\
\text { I5 } \\
-\end{array}$ & $\frac{5}{-}$ & $\frac{2}{16}$ \\
\hline
\end{tabular}

The symbol $(-)$ means no phenotype expected.

In relation to the ground color that must be shown by the action of $B$ on a gold bird, nothing was concluded from the obtained $S / s^{+}$males (since the cross was $\left.s^{+} / s^{+} \times S /-\right)$. However, in the females $\left(s^{+} /-\right)$it can be deduced that the action of the $B$ gene is the same on a silver as on a gold ground. In both cases the bars will be black and white alternately and they will never be black and gold. This contrasts with the black and gold barred plumage produced by the autosomal barring gene $A b$ on a gold ground color (PUNNETT and PEASE, I92I; MOORE and SMYTH, I972).

One of the $\mathrm{F}_{1}$ barred males $\left(E / e B / b^{+}\right)$was mated with its barred sisters $(E / e B /-)$. With the exception of barred or nonbarred gold females, all the expected phenotypes were obtained (Table 2). All the black barred males had alternate white bars, if they were silver $\left(S / s^{+}\right)$as well as if they were gold $\left(s^{+} / s^{+}\right)$; 
the same can be said of the black barred females $\left(S /\right.$ - or $s^{+} /$- respectively), as was previously found in the $F_{1}$ generation.

As chicks the black barred birds had the white patch on the head, but those that were gold barred did not. This indicates a different kind of $B$ action on the pheomalanins than on the eumelanins. Greater intensive dilution of the eumelanins happens also in the adult plumage since the golden barred birds have a less sharp or definite barring.

TABLE 2

$F_{2}$ generation segregation from some of the Table I matings

Ségrégation à la génération $F_{2}$, correspondant aux accouplements du tableau $I$

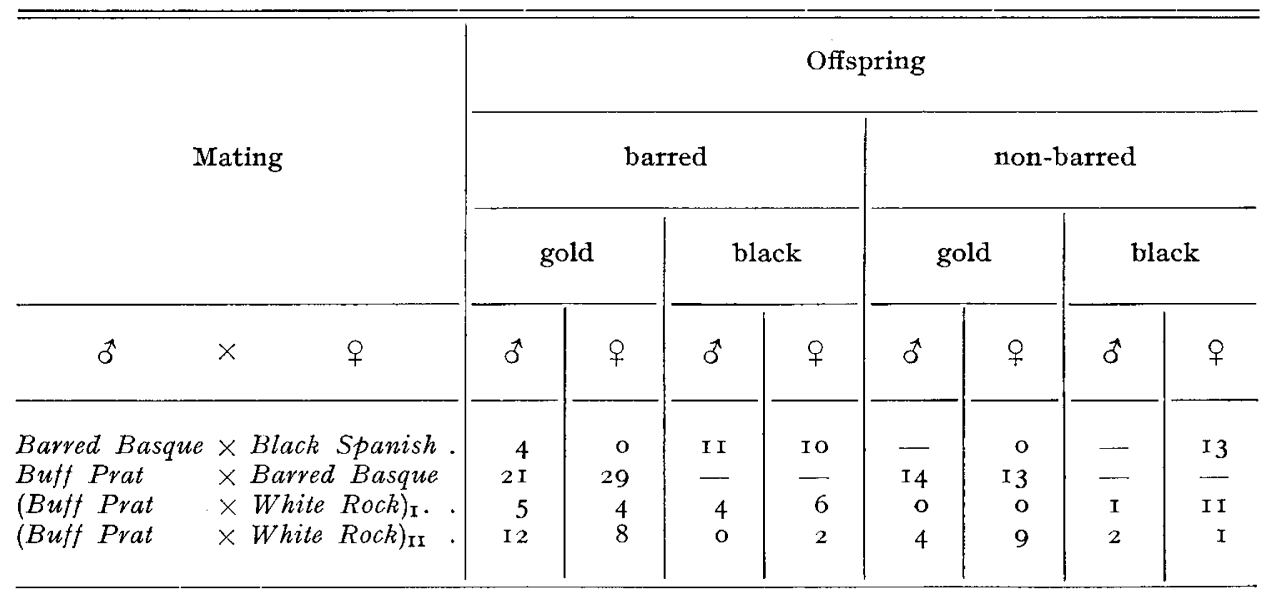

The symbol (-) means no phenotype expected, while o means no phenotype observed.

\section{Mating of Buff Prat male $\times$ Barred Basque female}

In order to see the $B$ action on a different gold ground color, a Buff Prat male, $e / e$, was mated to three Barred Basque females, $e / e$, (Table I). Gold barred males and gold non-barred females were only obtained as expected. The neck on females had more intensive gold color than the remaining plumage and the phenotype of the barred males was like that of the Barred Basque population. The black pigment was restricted to the tail and wings in both sexes, because of the columbian restriction factor. The male chicks did not have the white patch on the head in this case.

The phenotype of the $\mathrm{F}_{1}$ females was hard to classify as Basque or Prat; however, it was rather of the former type, except for the blue shanks from the Prat sex-linked gene $i d^{+}$(the cross was $\left.i d^{+} \mid i d^{+} \times I d /-\right)$. The results might indicate the dominance of the Basque E-locus allele even though the presence of the same allele is possible in both breeds, the two different phenotypes being produced by a dissimilar residual genotype. 
The dominance possibility is verified by crosses between Buff Prat males and nonbarred Basque females, whose detail is not included in this paper; all the obtained males (5I) and females (60) were classified as Basque type. The crosses between the Black Spanish and these two breeds also seem to confirm it; the progeny is black and red in both cases but the areas without eumalanin are larger in the Basque than in the Prat crosses. Furthermore, even some males with more red than black pigment are found in the Basque crosses.

In a mating of Buff Prat $\times$ Black Spanish, the $\mathrm{F}_{1}$ produced :

6 females, solid black.

7 females, black with red feathers on the neck.

I female, black with red feathers on the upper breast.

I6 males, black with red feathers on the hackle, saddle and wing-bows.

However, a mating of Basque $\times$ Black Spanish gave :

7 females, solid black.

5 females, black with neck red feathers.

2 females, black with breast red feathers.

I I females, black with neck and breast red feathers.

Io males, black with red areas on the hackle, saddle and wing-bows.

4 males, ted with the black pigment being restricted to the tail, hackle and wings.

5 males, red with black pigment on the tail, hackle, wings and the breast feather tips.

It is necessary to bear in mind that a Basque or Prat columbian restriction factor is present in the $F_{1}$ heterozygotes and then a possible interaction on the dominance of the Prat and Basque E-locus alleles with respect to the extended black could modify the true dominance of these $e$ 's.

The $\mathrm{F}_{2}$ generation of the initial cross Buff Prat $\times$ Barred Basque was obtained from two males and twenty females; it was impossible to separate the different kinds of barred or nonbarred gold phenotypes, males or females (Table 2).

An objective of our future studies is to test if the columbian factor in these gold Spanish breeds is the same. However, some data here seem informative. Gold barred birds without columbian black and white barred regions were not obtained in this $F_{2}$. Assuming that the sample size was large enough, it may be thought that the columbian factor from both breeds is the same. The presence of the columbian restriction gene Co (Sмyтн and Somes, I965; Smyth, I970). in the Buff Prat and the dark brown columbian-type restriction gene $D b$ (MOORE et al. I978) in the Basque breeds, or vice versa, does not seem likely because of the lack of birds with partial achromatosis in the $\mathrm{F}_{2}$ generation (SMYTH and MALONE, I979).

\section{Other types of mating}

The cross between the Buff Prat and the White Plymouth Rock (Table I) was made to compare the action of the barred alleles from the Basque and the Plymouth Rock breeds on the common genetic ground from the Buff Prat. Four males and seven females were mated. Barred males and nonbarred females were obtained with segregation of black and gold in both sexes. These results indicate heterozygosis in the Plymouth Rock E-locus; the allele besides the extended black is probably $e^{b}$, what is usual in the White Rock commercial populations (SмYтн, personal communication). Furthermore, the presence of $s^{+}$is obvious in this stock. 
The gold barred males were like the $\mathrm{F}_{1}$ males obtained from the Prat $\times$ Barred Basque crosses; the gold females were like the Prat females, showing that the $E$-locus allele of this breed is dominant to $e^{b}$ and therefore it may be the dominant wheaten, $e^{\mathrm{W} h}$.

The barred males receiving the $E$ allele had a larger proportion of black and white barred regions; they were not very different from the gold barred males in which the black and white barred feathers had a tendency to be located in the tail, hackle and wings, because of the Prat columbian restriction factor. All these deductions on dominance of $E, e$ alleles could be different in other cases because the dominance of $E$ on another more or less dominant allele, similar to $e^{\mathrm{W} h}$, is probably changed in presence of the barred and columbian factors.

The black females showed the usual incomplete dominance of $E$, with gold feathers in the breast and the neck.

Crosses between Barred Plymouth Rock males $(E / E B / B)$ and Gold Basque females produced black barred males and females (Table $I$ ) with a few gold flecks. The apparent greater dominance of allele $E$ might have two explanations : one could be that the Basque $e$ allele is more recessive than the Prat $e$ allele which is not likely bearing in mind the previous results. Another explanation might be that the $\mathrm{F}_{1}$ males from the mating Buff Prat $\times$ White Plymouth Rock were $s^{+} / s^{+}$while the $\mathrm{F}_{1}$ males from Barred Plymouth Rock $\times$ Gold Basque are $S / s^{+}$. In this way, the dominance of the black pigment should be enhanced in presence of the pheomelanin inhibition produced by the dominant silver allele.

With the $\mathrm{F}_{1}$ birds from the cross Buff Prat $\times$ White Rock, two kinds of mating were carried out according to the females phenotype. In each type of mating two black barred males $\left(E / e B / b^{+}\right)$were mated, with their black sisters in one case and with their gold sisters in the other (Table 2).

The proportion of gold flecks was small in the black barred males obtained in the former type of mating (I); this was probably because they were homozygous $E / E$. The same thing happened in the females. The gold barred males (that were homozygous for the Prat $e$ allele) were similar to those obtained in the $\mathrm{F}_{1}$ generation, while the gold barred females were like those obtained in the Buff Prat $\times$ Barred Basque $\mathbf{F}_{2}$ generation. In the second type of mating (II) all the barred males were classified as gold $(e / e)$, in spite of some of them being $E / e$ heterozygous; this confirms the results of the $\mathrm{F}_{1}$ generation.

Received for publication in November r 1980.

\section{Acknowledgements}

The authors wish to express their appreciation to Dr. R. CRAwford and Dr. P. Mérat for their critical review of the manuscript.

\section{Résumé}

L'action du facteur barré lié au sexe chez les races de poules espagnoles à plumage doré

Ce travail continue la description génétique des races espagnoles de poules et il étudie l'action du gène barré lié au sexe, observé chez des populations à plumage doré du Nord de 1'Espagne. Les accouplements entre la "Vasca " barrée et la "Castellana " noire, montrent que l'allèle de la 
première est identique a $B$. Dans les volailles " gold " $\left(s^{+}\right)$cet allèle prođuit des barres sans pigment alternant avec des barrures noires ou dorées, en présence de l'allèle "extended black ", $E$, ou d'autres allèles de ce locus. Le second phénotype (barré doré) ne présente pas la tache blanche occipitale chez le poussin d'un jour, typique du facteur barré lié au sexe.

En ce qui concerne l'allèle du locus $E$ présent dans les races "Vasca " et la " Prat ", la présence possible chez toutes deux du " wheaten dominant " $\left(e^{\mathrm{W} h}\right)$ est avancée. On suggère aussi l'identité possible du facteur du type "columbian " dans les deux races. La dominance du $E$ sur $e^{\text {Wh }}$ est très incomplète en présence du facteur barré et/ou "columbian".

\section{References}

CAmpo J. L., OROzCo F., I979. Détection des gènes responsables de la couleur du plumage chez les volailles espagnoles. Ann. Génét. Sél. Anim., 11, 7-I4.

HutT F. B., I949. Genetics of the Fowl. McGraw-Hill, New York, I-59o.

MoORE J. W., Sмyтн J. R., I972. Genetic factors associated with the plumage pattern of the Barred Fayoumi. Poultry Sci., 51, II49-I I56.

MoORe J. W., Classen H. L., Smyth J. R., r978. Further studies on the $D b$ plumage color locus in the fowl. Poultry Sci., 57, 829-834.

NICKERSON M., I944. An experimental analysis of barred pattern formation in feathers. $J$. Exp. Zool., 95, 361-398.

PunnetT R. C., PEASE M. S., I92I. Genetic studies in poultry. IV. On the barred plumage of certain breeds. J. Genetics, 11, 235-240.

PunnetT R. C., PEase M. S., I928. Genetic studies in poultry. VI. The Gold Barred Rock. J. Genetics, 19, 337-350.

SMYTH J. R., I970. Genetic basis for plumage color pattern in the New Hampshire fowl. $J$. Hevedity, 61, 280-283.

Sмхтн J. R., Somes R. G., I965. A new gene determining the columbian feather pattern in the fowl. J. Hevedity, 56, r $50-156$.

Smyth J. R., Malone G. W., I979. Evidence that plumage color genes $m i$ and $D b$ are identical. Poultry Sci., 58, I I08-1 I09.

Somes R. G., 1978. Registry of Poultry Genetic Stocks in North America, England, France, Spain and the Netherlands. The University of Connecticut, Storrs, I-76. 